\title{
Strategi Pengembangan Usaha Keripik Tike (Eleocharis Dulcis) Pada Industri Rumah Tangga Di Kecamatan Losarang Kabupaten Indramayu
}

\author{
Kerin Alfebry ${ }^{1}$, Entus Hikmana ${ }^{2}$, Karto ${ }^{3}$ \\ 1,2,3 Program Studi Agribisnis, Fakultas Pertanian Universitas Wiralodra, \\ Email: alfebry@gmail.com ${ }^{1}$, entushikmana@gmail.com ${ }^{2}$, karto@gmail.com ${ }^{3}$
}

\begin{abstract}
ABSTRAK
Tujuan dari penelitian ini adalah 1) untuk mengetahui dan menganalisis kekuatan, kelemahan, peluang, dan ancaman yang dihadapi dalam usaha keripik tike di Kecamatan Losarang Kabupaten Indramayu, 2) menetapkan strategi alternatif untuk pengembangan usaha keripik tike di Kecamatan Losarang Kabupaten Indramayu.

Penelitian ini dilakukan di Kecamatan Losarang Kabupaten Indramayu. Pengambilan sampel dengan menggunakan cara sensus dengan jumlah responden sebanyak empat pengusaha. Metode penelitian yang digunakan survei, dengan desain penelitian menggunakan survei deskriptif. Jenis data yang digunakan yaitu data primer dan data sekunder. Teknik pengumpulan data dengan menggunakan wawancara dan kuesioner, serta data yang diperoleh, dianalisis dengan menggunakan analisis SWOT, matriks QSPM, sehingga diperoleh strategi prioritas yang tepat bagi pengusaha keripik tike di Kecamatan Losarang Kabupaten Indramayu.

Hasil penelitian yang diperoleh adalah bahwa kekuatan home industry keripik tike di Kecamatan Losarang: 1) Memiliki kemauan dan keuletan yang tinggi dari pemilik dalam mengelola usaha, 2) Produknya banyak diminati. 3) Memanfaatkan warga sekitar sebagai karyawan. 4) Produk berkualitas dan memiliki izin. Adapun kelemahan home industry keripik tike di Kecamatan Losarang: 1) Kurang adanya promosi produk. 2) Masih menggunakan cara tradisional. 3) Bahan baku relatif sulit diperoleh. 4) Tata kelola keuangan masih sederhana. Sedangkan peluang home industry keripik tike di Kecamatan Losarang:1) Dukungan dari pemerintah daerah setempat. 2) Tersedianya fasilitas informasi untuk memperluas areal promosi dan pemasaran yang lebih luas 3) Permintaan tinggi pada saat harihari perayaan. 4) Peluang Pasar Masih Terbuka. Serta ancaman home industry keripik tike di Kecamatan Losarang: 1) Duplikasi produk oleh usaha lain. 2) Kurang terjamin ketersediaan bahan baku. 3) Penurunan daya beli pelanggan. 4) Fluktuasi harga bahan baku.

Adapun prioritas strategi diperoleh adalah strategi pasar dan pengembangan produk atau strategi integratif (integrasi ke depan, integrasi ke belakang, integrasi horizontal). Dengan strategi yang tepat perusahan dapat menjalin kerjasama dengan pemerintah setempat untuk memperoleh bahan baku dan informasi guna meningkatkan peminat dan memperluas areal promosi usaha keripik tike.
\end{abstract}

Kata Kunci : Strategi pengembangan usaha, kerupuk tike, strategi integratif

\section{I.PENDAHULUAN}

Peran industri pengolahan pertanian memiliki peranan penting dalam pembangunan pertanian.Hal ini dapat dilihat dari kontribusinya dalam hal meningkatkan pendapatan pelaku agribisnis, menyerap tenaga kerja, meningkatkan perolehan devisa, dan mendorong tumbuhnya industri lain. Secara eksplisit peran industri pengolahan pertanian tersebut adalah memproses bahan nabati (yang berasal dari tanaman) atau hewani (yang dihasilkan oleh hewan), yang mencakup proses pengubahan dan pengawetan melalui perlakuan fisik, kimiawi, penyimpanan, dan pengemasan serta distribusi. Produk agroindustri tersebut dapat merupakan produk akhir yang siap dikonsumsi ataupun sebagai produk bahan baku industri lainnya. (Soekartawi, 2001).

Kabupaten Indramayu merupakan salah satu kabupaten di Provinsi Jawa Barat yang memiliki banyak industri kecil dan rumah tangga yang tersebar di setiap kecamatan bahkan desa. Home industri yang tergolong ke dalam industri kecil ini bersifat informal yang pengelolaannya dikelola oleh perseorangan atau ruang lingkup rumah tangga. Salah satu industri kecil yang ada di Kabupaten 
Indramayu adalah home industri keripik tike yang merupakan produksi khas wilayah Indramayu. Home industri keripik tike tersebut di Kabupaten Indramayu tersebar besar di Kecamatan Losarang dan sebagian kecil di Kecamatan Karangampel.

Usaha keripik tike di Kecamatan Losarang umumnya sudah berlangsung selama 40 tahun lebih. Dalam perkembangannya usaha ini menghadapi beberapa kendala anatara lain: a) keterbatasan bahan baku umbi tike pada saat musim hujan, b) keterbatasan modal, c) belum terkondisikannya usaha industri setempat dikarenakan tidak adanya lembaga ekonomi seperti koperasi atau badan lainnya yang dapat mengatur kebijakan usaha setempat yang dapat menimbulkan persaingan usaha yang tidak sehat antar pengusaha dalam hal penentuan harga jual dan pendistribusian pasar.

Menurut data Diskoperindag pada tahun 2014 jumlah pemilik usaha keripik tike di Kecamatan Losarang berjumlah 28 pengusaha, 22 pengusaha keripik tike terdapat Desa Jumbleng dan 6 pengusaha keripik tike terdapat di Desa Pangkalan.Tetapi setiap tahunnya keberadaan pengusaha keripik tike mengalami fluktuasi, dikarenakan bahan baku yang didapat musiman dan sulit didapat.

Tabel 1. Daftar Sentra Industri Kecil dan Menengah Keripik Tike Di Kecamatan Losarang

\begin{tabular}{cccr}
\hline No. & Desa & Kecamatan & Unit Usaha \\
\hline 1. & Jumbleng & Losarang & 22 \\
2. & Pangkalan & Losarang & 6 \\
\hline & & & 28 \\
\hline
\end{tabular}

Sumber : Dinas Koperasi, UKM, Perindustrian dan Perdagangan Kabupaten Indramayu,2021

Dalam usaha pengembangan keripik tike tersebut di atas, diperlukan perencanaan strategi pengembangan usaha keripik, agar usahanya dapat berjalan dengan optimal sehingga dapat bersaing dengan usaha sejenis lainnya. Untuk hal tersebut diperlukan strategi pengembangan usaha keripik tike pada industri rumah tangga di Kecamatan Losarang, Kabupaten Indramayu.

\section{II.METODE PENELITIAN}

Metode penelitian yang digunakan dalam penelitian ini menggunakana metode survey terhadap fakta-fakta dan gejala-gejala yang ada serta mencari keterangan-keterangan secara faktual, baik tentang institusi sosial, ekonomi, atau politik dari suatu kelompok manusian ataupun suatu daerah (Nazir,1988). Sedangkan desain penelitian yang digunakan adalah suvei deskriftif yang merupakan desain penelitian yang digunakan untuk mencari fakta dengan interpretasi yang tepat terhadap suatu objek, status kelompok manusia, suatu set kondisi, suatu sistem pemikiran dan suatu kelas tertentu. Untuk mendukung desain penelitian tersebut, ditunjang dengan analisis SWOT, IFE dan EFE analisis serta Quantitative Strategik Planning Matriks sehingga diperoleh alternatif strategi yang tepat.

\section{III.HASIL DAN PEMBAHASAN}

\section{Analisis Faktor Internal Usaha Keripik Tike}

1.Faktor Kekuatan Perusahaan

a.Tingginya kemauan dan keuletan pemilik dalam mengelola usaha

Kemauan dan keuletan pemilik usaha keripik tike dalam menjalankan usaha keripik tike ini menjadi modal utama. Dengan adanya keamauan yang kuat dari pemilik usaha keripik tike sehingga dapat memotivasi diri maupun tenaga kerjanya. Keuletan pemilik ditunjukan untuk menambah pengetahuan pemilik sehingga mampu menghasilan produk yang beragam. Hal ini merupakan kekuatan yang dimiliki pengusaha keripik tike, sehingga usaha keripik tike ini masih ada hingga sekarang.

\section{b. Produknya banyak diminati}

Produk olahan keripik tike ini banyak diminati karena rasanya yang berbeda dan ukuran dari keripik tikenya lebih besar dari pada usaha keripik tike di daerah lain di Indramayu. c.Memanfaatkan tenaga kerja dari lingkungan sekitar

Pemanfaatan masyarakat sekitar sebagai karyawan yaitu untuk upah tenaga kerja yang murah, mengurangi angka pengangguran di desa serta mensejahterakan masyarakat sekitar home industry tersebut. 
d.Produk berkualitas dan memiliki izin

Produk berkualitas yang ditentukan oleh bahan baku yang bermutu. Pemilihan bahan baku yang akan dipakai dalam berproduksi harus dalam keadaan segar. Produk keripik tike di Desa Jumbleng ini beberapa telah memliki P-IRT dan telah mendapatkan sertifikasi halal dari MUI.

\section{Faktor Kelemahan Perusahaan}

a.Kurang adanya promosi produk

Promosi yang dilakukan masih kurang dalam usaha keripik tike ini, kualitas produk yang sudah memiliki izin belum dapat bersaing dengan produk lain yang sudah banyak melakukan promosi dan mampu menembus pasar luar Indramayu.

b.Dalam produksi masih menggunakan cara tradisional

Pengolahan dalam produksi keripik tike sebagian besar masih menggunakan cara tradisional, dengan menggunakan alat seadanya, tanpa menggunakan mesin atau alat pemecah bahan baku tike maupun vakum priying.

c.Bahan baku relatif sulit diperoleh

Bahan baku yang diperoleh berasal dari Cilacap. Bahan baku tidak selalu ada setiap bulannya. Disaat bukan musimnya bahan baku susah dicari dan pengusaha sementara tidak memproduksi terlebih dahulu.

d.Tata kelola keuangan usaha masih sederhana

Untuk tata kelola keuangan masih lemah, disebabkan oleh faktor pemasaran, keuangan dan administrasi yang belum mampu dikelola secara optimal oleh pengusaha keripik tike.

\section{Analisis Faktor Eksternal Usaha Keripik Tike}

1.Faktor Peluang Usaha

a.Dukungan dari pemerintah daerah setempat

Peran dukungan dari dinas terkait terutama dari Dinas Koperasi, UKM, dan perdagangan dalam memberikan pelatihan berwirausaha dan fasilitas serta perizinan.

b.Tersedianya fasilitas informasi untuk promosi dan pemasaran lebih luas

Pengusaha keripik tike dapat memanfaatkan teknologi dan informasi untuk memperluas jangkauan pemasaran produk keripik tike dan dapat menciptakan inovasi pada produk keripik tike.

c.Permintaan meningkat saat hari-hari besar keagamaan

Penjualan produk disaat hari-hari besar ini dapat dimanfaatkan untuk mendapatkan keuntungan yang lebih dibandingkan dengan hari-hari biasa, dengan cara memperbanyak produksi.

d.Peluang Pasar Masih Terbuka

UKM yang bergerak dalam usaha keripik tike masih sedikit, sehingga menjadi peluang bagi pengusaha keripik tike di Kecamatan Losarang Kabupaten Indramayu menjadi pemasok utama permintaan keripik tike di seluruh wilayah Indramayu dan sekitarnya.

2.Faktor Ancaman Usaha

a.Duplikasi produk oleh usaha lain

Duplikasi produk dapat terjadi, ini menjadi ancaman bagi pengusaha keripik tike, dikarenakan produksi dan keuntungan menurun.

b.Ketidaktersediaan bahan baku karena kurang terjangkaunya ketersediaan bahan baku

Bahan baku yang digunakan merupakan tanaman yang musiman, dan juga didapat bukan berasal dari Indramayu tetapi berasal dari Cilacap. Pasokan bahan baku menjadi sedikit, akibatnya menggangu proses produksi menjadi terhambat dan produksi tidak kontinyu.

c.Penurunan daya beli konsumen

Daya beli konsumen menurun dikarenakan bahan baku yang diperoleh mengalami kenaikan disaat pasokan yang dikirimkan sedikit, hal ini mengalami pengurangan isi dari keripik tike tersebut dan kurangnya inovasi pada keripik tike tersebut. Hal ini juga dapat berdampak pada daya beli pelanggan keripik tike yang terus menuru sehingga jumlah pembelinya kurang.

d.Fluktuasi harga bahan baku

Naik turunnya harga bahan baku tike menjadi ancaman dalam usaha keripik tike ketika memperoleh bahan baku dibukan musimnya, hal ini dikarenakan harga yang terlalu tinggi yang dijual 
oleh tengkulak tike, dan juga modal yang dimiliki pengusaha keripik tike tidak terlalu besar. Oleh karena itu usaha ini terhambat ketika bahan baku sedikit.

\section{Analisis matriks SWOT}

\section{Matriks Lingkungan Internal dan Eksternal} berikut:

Setelah dianalisis menggunakan SWOT, maka diperoleh hasil faktor-faktor analisis sebagai

Berdasarkan matriks SWOT pada Tabel 2, maka dihasilkan strategi yang merupakan penggabungan dari berbagai strategi, yang meliputi strategi SO, WO, ST, dan WT, yang dihasilkan sebagai berikut :

\section{Strategi Strenght-Opportunity (S-O) Threats}

Strategi S-O adalah strategi yang menggunakan kekuatan yang mengambil keuntungan dari peluang yang ada. Beberapa strategi yang dapat diterapkan perusahaan, yaitu:

a.Menjalin kerjasama dengan pemerintah desa setempat untuk memperoleh bahan baku dan informasi guna mendukung peminat dan memperluas areal promosi usaha keripik tike.

\section{Tabel 2. Matriks SWOT Usaha Keripik Tike}

\begin{tabular}{|c|c|c|}
\hline Faktor Internal & \begin{tabular}{l}
\multicolumn{1}{c}{ Kekuatan (S) } \\
1. Tingginya kemauan dan keuletan \\
pemilik dalam mengelola usaha \\
2. Produknya banyak diminati \\
3. Memanfaatkan warga sekitar \\
sebagai karyawan \\
4. Produk berkualitas dan memiliki \\
izin
\end{tabular} & $\begin{array}{l}\text { Kelemahan (W) } \\
\text { 1. Kurang adanya promosi } \\
\text { 2. Menggunakan cara } \\
\text { tradisional } \\
\text { 3. Bahan baku relatif } \\
\text { diperoleh } \\
\begin{array}{l}\text { 4. Pembukuan } \\
\text { sederhana }\end{array}\end{array}$ \\
\hline \multicolumn{3}{|l|}{ Faktor Ekternal } \\
\hline $\begin{array}{l}\text { Peluang }(\mathrm{O}) \\
\text { 1. Dukungan dari pemerintah } \\
\text { daerah setempat } \\
\text { 2. Tersedianya fasilitas informasi } \\
\text { untuk memperluas areal } \\
\text { promosi dan pemasaran yang } \\
\text { lebih luas } \\
\text { 3. Permintaan tinggi pada saat } \\
\text { hari-hari perayaan } \\
\text { 4. Peluang Pasar Masih Terbuka }\end{array}$ & S-O & W-O \\
\hline $\begin{array}{l}\quad \text { Ancaman (T) } \\
\text { 1. Duplikasi produk oleh usaha } \\
\text { lain } \\
\text { 2. Ketidaktersediaan bahan baku } \\
\text { karena kurang terjangkaunya } \\
\text { ketersediaan bahan baku } \\
\text { 3. Penurunan Daya Beli } \\
\text { Konsumen } \\
\text { 4. Fluktuasi harga bahan baku }\end{array}$ & S-T & W-T \\
\hline
\end{tabular}

b.Memanfaatkan sumber daya manusia yang ada di sekitar wilayah usaha agar menyediakan lapangan pekerjaan dan menghasilkan produk yang berkualitas untuk meningkatkan permintaan, memperluas jangkauan pasar bagi usaha keripik tike yang terus meningkat.

\section{Strategi Weakness Opportunity (W-O)}

Strategi W-O adalah strategi yang mengatasi kelemahan dengan memanfaatkan peluang yang ada. Alternatif strategi W-O dapat dirumuskan sebagai berikut:

a.Memanfaatkan dukungan pemerintah untuk mempromosikan keripik tike agar keripik tike dapat menembus pasar dan banyak diminati oleh masyarakat. 
b.Manfaatkan teknologi untuk mempermudah dalam proses pembuatan dan pemasaran keripik tike.

\section{Strategi Strenght-Opportunity (S-T) Threats Weakness}

Strategi S-T adalah srategi yang memanfaatkan kekuatan untuk menghindari ancamanancaman yang ada. Beberapa strategi yang dapat diterapkan perusahaan, yaitu:

a.Menciptakan inovasi pada keripik tike agar duplikasi produk oleh usaha lain tidak terjadi dan mampu bersaing dengan produk sejenis.

b.Bekerjasama dengan pemasok bahan baku tike agar usaha berjalan secara kontinyu.

c.Melakukan diversifikasi produk agar konsumen keripik tike dapat memilih sesuai dengan keinginannya.

\section{Strategi Weakness- Threats ( W-T)}

Strategi yang memanfaatkan kelemahan untuk menghindar dari ancaman ancaman yang ada.

Beberapa strategi yang dapat diterapkan:

a.Melakukan promosi produk keripik tike secara intensif dan efektif melalui media masa.

b.Menambah tenaga kerja dibagian pemasaran untuk meningkatkan penjualan.

\section{Analisis Matriks Internal Factor Evaluation (IFE)}

Setelah dianalisis menggunakan SWOT, maka diperoleh identifikasi terhadap faktor internal yang meliputi kekuatan dan kelemahan sebagai berikut:

Tabel 3. Matris IFE (Internal Factor Evaluation)

\begin{tabular}{lcccc}
\hline \multicolumn{1}{c}{ Kekuatan $(\mathrm{S})$} & $\begin{array}{c}\text { Bobot } \\
(\mathrm{B})\end{array}$ & $\begin{array}{c}\text { Rating } \\
(\mathrm{R})\end{array}$ & $\begin{array}{c}\text { Skor } \\
(\mathrm{BxR})\end{array}$ & Prioritas \\
\hline $\begin{array}{l}\text { 1. Tingginya kemauan dan keuletan pemilik dalam } \\
\text { mengelola usaha }\end{array}$ & 0,140 & 3 & 0,420 & 3 \\
2. Produknya banyak diminati & 0,140 & 3 & 0,420 & 3 \\
3. Memanfaatkan warga sekitar sebagai karyawan & 0,132 & 2 & 0,264 & 3 \\
4. Produk berkualitas dan memiliki izin & 0,154 & 3 & 0,462 & 4 \\
\hline Jumlah & & $\mathbf{1 1}$ & $\mathbf{1 , 5 6 6}$ \\
\hline Kelemahan (W) & & & & 3 \\
5. Kurang adanya promosi & 0,103 & 3 & 0,309 & 3 \\
6. Menggunakan cara tradisional & 0,103 & 2 & 0,206 & 3 \\
7. Bahan baku relatif sulit diperoleh & 0,125 & 3 & 0,375 & 3 \\
8. Tata kelola keuangan masih sederhana & 0,103 & 3 & 0,309 \\
\hline Jumah & & $\mathbf{1 1}$ & $\mathbf{1 , 1 9 9}$ \\
\hline
\end{tabular}

Hasil matriks IFE pada Tabel 3. Dapat digambarkan bahwa total skor faktor IFE diperoleh 2,765. Nilai tersebut menunjukan bahwa Usaha Keripik Tike di Kecamatan Losarang Kabupaten Indramayu menunjukkan memiliki kekuatan internal tinggi. Nilai skor untuk kekuatan adalah sebesar 1.566 sedangkan nilai skor untuk kelemahan adalah 1.199. Nilai akhir skor total kekuatan yang lebih besar dari pada kelemahannya menunjukan bahwa dalam menjalankan usaha, usaha keripik tike di Kecamatan Losarang menunjukkan memiliki kekuatan yang lebih tinggi dibanding kelemahan yang dimiliki.

\section{Analisis Matriks Eksternal Factor Evaluation (EFE)}

Setelah dianalisis menggunakan SWOT, maka diperoleh identifikasi terhadap faktor eketernal yang meliputi peluang dan ancaman sebagai berikut: 
Tabel 4. Matriks EFE (Ekstrenal Factor Evaluation)

\begin{tabular}{|c|c|c|c|c|}
\hline Peluang $(\mathrm{O})$ & $\begin{array}{l}\text { Bobot } \\
\text { (B) }\end{array}$ & $\begin{array}{l}\text { Rating } \\
(\mathrm{R})\end{array}$ & $\begin{array}{l}\text { Skor } \\
(\mathrm{BxR})\end{array}$ & Prioritas \\
\hline 1. Dukungan dari pemerintah daerah setempat & 0,141 & 4 & 0,564 & 4 \\
\hline $\begin{array}{l}\text { 2. Tersedianya fasilitas informasi untuk memperluas areal } \\
\text { promosi dan pemasaran yang lebih luas }\end{array}$ & 0,134 & 4 & 0,536 & 4 \\
\hline 3. Permintaan tinggi pada hari-hari besar & 0,121 & 3 & 0,363 & 3 \\
\hline 4. Peluang Pasar Masih Terbuka & 0,141 & 4 & 0,564 & 4 \\
\hline Jumlah & & 15 & 2,027 & \\
\hline Ancaman $(\mathrm{T})$ & & & & \\
\hline 5. Duplikasi produk oleh usaha lain & 0,134 & 3 & 0,402 & 3 \\
\hline $\begin{array}{l}\text { 6. Ketidaktersediaan bahan baku karena perubahan musim } \\
\text { yang signifikan }\end{array}$ & 0,094 & 2 & 0,188 & 2 \\
\hline 7. Daya beli pelanggan menurun & 0,094 & 3 & 0,282 & 3 \\
\hline 8. Fluktuasi harga bahan baku & 0,141 & 2 & 0,282 & 3 \\
\hline Jumah & & 10 & 1,154 & \\
\hline Jumlah Total & & 25 & 3,181 & \\
\hline
\end{tabular}

Berdasar hasil matriks EFE pada Tabel 4 di atas diperoleh total skor faktor strategis ekternal 3,181. Nilai tersebut menunjukan bahwa usaha keripik tike di Kecamatan Losarang Kabupaten Indramayu memiliki rata-rata kekuatan eksternal yang tinggi, terdiri atas skor untuk peluang sebesar 2,027 dan skor untuk ancaman sebesar 1,154. Dari nilai skor tersebut, menunjukkan bahwa faktor peluang usaha keripik tike memiliki peran lebih besar dibanding ancamannya, sehingga dalam menjalankan usaha keripik tike, pengusaha harus dapat memanfaatkan peluang dalam mengurangi atau meminimalisir ancaman.

\section{Analisis Matriks Internal-Eksternal (IE)}

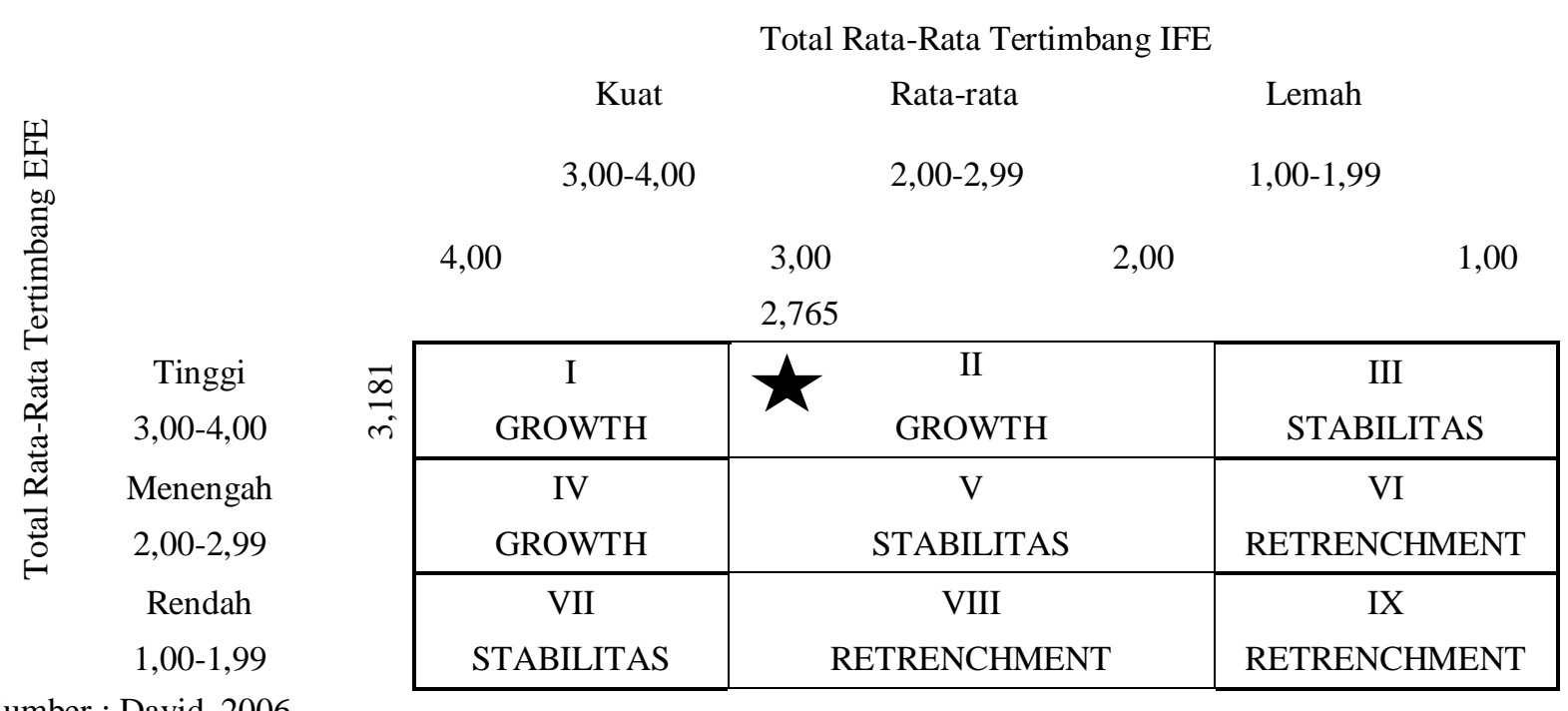

Sumber : David, 2006

Pada matriks I-E ditunjukan bahwa posisi usaha keripik tike di Kecamatan Losarang Kabupaten Indramayu berada pada kuadran II yang artinya tumbuh berkembang. Strategi yang tepat dalam kondisi ini adalah strategi intensif (penetrasi pasar, pengembangan pasar, dan pengembangan produk). 


\section{Matriks QSPM (Qualitatif Strategic Planning Matriks)}

Berdasarkan strategi alternatif yang dihasilkan dari anallisis SWOT, maka pemilihan strategi terbaik menurut prioritas dengan menggunakan alat bantu analisis matriks QSPM (Qualitatif Strategic Planning Matriks). Analisis ini digunakan untuk menganalisis strategi alternatif secara objektif, berdasarkan komponen faktor-faktor strategi internal dan eksternal.

Dari beberapa strategi yang dihasilkan dalam analisis SWOT, maka dipilih 3 strategi alternatif yang kuat untuk pengembangan usaha keripik tike di Kecamatan Losarang Kabupaten Indramayu, yaitu sebagai berikut:

Tabel 5. Matriks QSPM Usaha Keripik Tike

\begin{tabular}{|c|c|c|c|c|c|c|c|}
\hline \multirow{3}{*}{$\begin{array}{l}\text { Faktor } \\
\text { Kunci }\end{array}$} & \multirow{3}{*}{ Bobot } & \multicolumn{6}{|c|}{ Alternatif Strategi } \\
\hline & & \multicolumn{2}{|c|}{ Strategi-1 } & \multicolumn{2}{|c|}{ Strategi-2 } & \multicolumn{2}{|c|}{ Strategi-3 } \\
\hline & & AS & TAS & AS & TAS & AS & TAS \\
\hline \multicolumn{8}{|l|}{ I.IFE } \\
\hline 1. & 0,140 & 3 & 0,420 & 4 & 0,560 & 3 & 0,420 \\
\hline 2. & 0,140 & 4 & 0,560 & 3 & 0,420 & 3 & 0,420 \\
\hline 3. & 0,132 & 3 & 0,396 & 3 & 0,396 & 3 & 0,396 \\
\hline 4. & 0,154 & 4 & 0,616 & 3 & 0,462 & 4 & 0,616 \\
\hline 5. & 0,103 & 3 & 0,309 & 3 & 0,309 & 3 & 0,309 \\
\hline 6. & 0,103 & 2 & 0,206 & 3 & 0,309 & 2 & 0,206 \\
\hline 7. & 0,125 & 3 & 0,375 & 3 & 0,375 & 2 & 0,250 \\
\hline 8. & 0,103 & 3 & 0,309 & 2 & 0,206 & 2 & 0,206 \\
\hline \multicolumn{8}{|l|}{ II.EFE } \\
\hline 1. & 0,141 & 4 & 0,564 & 3 & 0,423 & 3 & 0,423 \\
\hline 2. & 0,134 & 3 & 0,402 & 4 & 0,536 & 4 & 0,536 \\
\hline 3. & 0,121 & 3 & 0,363 & 2 & 0,242 & 2 & 0,242 \\
\hline 4. & 0,141 & 3 & 0,423 & 3 & 0,423 & 3 & 0,423 \\
\hline 5. & 0,134 & 4 & 0,536 & 2 & 0,268 & 3 & 0,402 \\
\hline 6. & 0,094 & 3 & 0,282 & 3 & 0,282 & 2 & 0,188 \\
\hline 7. & 0,094 & 3 & 0,282 & 2 & 0,188 & 2 & 0,188 \\
\hline 8. & 0,141 & 3 & 0,423 & 3 & 0,423 & 2 & 0,282 \\
\hline \multicolumn{2}{|r|}{ Jumlah } & & 6,466 & & 5,822 & & 5,507 \\
\hline
\end{tabular}

Berdasar Tabel 6 tersebut di atas, maka tahap selanjutnya untuk mengambil keputusan menentukan prioritas strategi yang tepat dalam usaha keripik tike di Kecamatan Losarang Kabupaten Indramayu, maka dilakukan dengan menggunakan analisis QSPM (Qualitatif Strategic Planning Matriks), untuk menentukan strategi apa yang cocok untuk usaha keripik tike di Kecamatan Losarang Kabupaten Indramayu. Berdasarkan hasil analisis menggunakan QSPM (Qualitatif Strategic Planning Matriks), maka urutan peringkat prioritas strategi adalah sebagai berikut: 
Tabel 6. Strategi Yang Tepat Hasil Analisis Matriks QSPM

Strategi 1 Menjalin kerjasama dengan pemerintah setempat untuk memperoleh bahan 6,466 baku dan informasi guna meningkatkan peminat dan memperluas areal promosi usaha keripik tike.

Strategi 2 Memanfaatkan dukungan pemerintah untuk mempromosikan keripik tike agar keripik tike dapat menembus pasar dan banyak diminati oleh masyarakat.

Strategi 3 Manfaatkan teknologi untuk mempermudah dalam proses pembuatan dan 5,507 pemasaran keripik tike.

\section{IV.SIMPULAN DAN SARAN}

\subsection{Simpulan}

Berdasarkan hasil analisis yang telah dilakukan pada penelitian usaha keripik tike di Kecamatan Losarang Kabupaten Indramayu ini, maka diperoleh kesimpulan sebagai berikut :

1. Berdasarkan hasil analisis, diperoleh kekuatan dalam pengembangan usaha keripik tike, antara lain, tingginya kemauan dan keuletan pemilik dalam mengelola usaha, produk banyak diminati, memanfaatkan warga sekitar sebagai karyawan, produk berkualitas dan memiliki izin. serta kelemahan yang perlu diperhatikan kurang adanya promosi, usaha tradisional, bahan baku relatif sulit, pembukuan masih sederhana. Sedangkan faktor peluang usaha keripik tike antara lain Dukungan dari pemerintah setempat, adanya teknologi dan informasi untuk memperluas promosi dan pasar, permintaan tinggi pada saat hari-hari besar keagamaan, peluang pasar masih terbuka, sedangkan faktor ancaman antara lain duplikasi produk oleh usaha lain, ketidaktersediaan bahan baku sepanjang tahun, penurunan daya beli konsumen, dan fluktuasi harga bahan baku.

2. Berdasarkan analisis QSPM maka diperoleh prioritas strategi utama yang dapat diterapkan pada usaha keripik tike di Kecamatan Losarang Kabupaten Indramayu, adalah Menjalin kerjasama dengan pemerintah setempat untuk memperoleh bahan baku dan informasi guna meningkatkan peminat dan memperluas areal promosi usaha keripik tike; Memanfaatkan dukungan pemerintah untuk mempromosikan keripik tike agar keripik tike dapat menembus pasar dan banyak diminati oleh masyarakat dan Manfaatkan teknologi untuk mempermudah dalam proses pembuatan dan pemasaran keripik tike.

$$
3 \text {. }
$$

\subsection{Saran-saran}

Berdasarkan hasil penelitian dan simpulan maka ada hal-hal yang dapat disarankan antara lain

1. Pengusaha keripik tike di Kecamatan Losarang Kabupaten Indramayu sebaiknya melakukan promosi dengan memanfaatkan media sosial ataupun mengikuti pameran kuliner yang mungkin diadakan oleh pemerintah daerah setempat.

2. Pengusaha keripik tike harus memiliki banyak saluran produsen yang dapat menyediakan bahan baku agar produksi tetap berjalan.

3. Memanfaatkan kredit yang ditawarkan oleh pihak lembaga keuangan untuk mengembangkan usahanya agar menjadi maju.

\section{Ucapan Terima Kasih}

Ucapan Terimaksih saya ucapkan kepada Fakultas Pertanian dan LPPM UNWIR yang telah membantu dalam penelitian ini Sehingga penelitiian ini dapat terlaksana dengan baik 
DAFTAR PUSTAKA

Badan Pusat Statistik (BPS) Indramayu. Indramayu Dalam Angka 2017. Indramayu.

Aji Bayu P, 2012. Strategi Pengembangan Agroindustri Keripik Pisang di Kecamatan Tawangmangu Kabupaten Karanganyar. Surakarta.

Chooi, Ong Hean, 2003. Sayuran dan Khasiat Makanan dan Obatan. Utusan Publication and Distributors Sdn. Kuala Lumpur.

David, F.R. 2004. "Manajemen Strategis: Konsep. Edisi ketujuh". PT. Prenhallindo, Jakarta.

David, F.R. 2006. "Strategic Management". Concepts and Cases, $10^{\text {th }}$ Ed. Francis Marion university Florence, South Carolina.

Dinas Koperasi, UKM, Perindustrian dan Perdagangan Kabupaten Indramayu 2014. Daftar Pemilik Usaha Industri Keripik Tike Di Desa Jumbleng pada Tahun 2014.

Dinas Koperasi, UKM, Perindustrian dan Perdagangan Kabupaten Indramayu 2017. Daftar Sentra Industri Kecil dan Menengah pada Tahun 2017.

Dirgantoro C. 2004. Manajemen Stratejik. Jakarta : Gramedia.

Downey, W. D. Dan Steven P. Erickson, 1987. Manajemen Agribisnis. Erlangga, Jakarta.

Hariyadi P. 2011. Riset dan Tenologi Pendukung peningkatan Kedaulatan Rakyat. Jurnal

Hariadi. 2005 Indriyanto, Gitosudarmo. 2001. Manajemen Strategis. Yogyakarta.

Jauch Lawrence R. \& Glueck William F., (1989), Manajemen Dan Strategis

Kebijakan Perusahaan. Jakarta : Erlangga.

Kinner, TC dan JR Taylor. 1991. Marketing Research: an Applied Approach. Mc

Graw-Hill. New York.

Nazir. 1988. Metode Penelitian. Jakarta : Ghalia Indonesia.

Oase, 2017. Budaya Indonesia Elemen Budaya Makanan atau Minuman Provinsi Jawa Barat Asal Daerah Indtamayu. https://budaya-indonesia.org/Keripik-Tike [ dikutip 10 Oktober 2018]

Pasambuna M, 2003. Kajian Perencanaan dan Pengembangan Agroindustri Perikanan Rakyat di Kabupaten Bolaan Mongondow, Provinsi Sulawesi Utara (Tesis). Bogor : Program Pasca Sarjana, Institut Pertanian Bogor.

Philip Kotler, 2002. Manajemen Pemasaran, Edisi Millenium, Jilid 2, PT. Prenhallindo, Jakarta.

Pratomo TS, Soejoedono AR. 2002. Ekonomi Skala Kecil/Menengah dan Koperasi. Ghalila Indonesia : Jakarta.

Profil Desa Jumbleng Tahun 2014.

Purwanto I. 2008. Manajemen Strategi. Bandung : CV. Yrama Widya.

Rangkuti, Freddy. 2009. Analisis SWOT Teknik membedah kasus bisnis. Gramedia. Jakarta.

Safinah Surya Hakim, 2018. Menganyam Purun Untuk Kelestarian Gambut.

Saragih B. 2010. Suara Dari Bogor : Membangun Opini Sistem Agribisnis. Bogor

PT. Penerbit IPB Press dan Food and Agribisnis Center.

Siagian, Sondang P. 2011. Manajemen Strategik. Jakarta : PT Bumi Aksara.

Soeharjo, 1991. Konsep dan Ruang Lingkup Agroindustri dalam Kumpulan Makalah Seminar Agribisnis. Buku I. Jurusan Ilmu-ilmu Sosial Ekonomi Pertanian. Fakultas Pertanian IPB. Bogor.

Soekartawi, 2001. Pengantar Agroindustri. PT. Raja Grafindo Persada. Jakarta.

Sonjanawati, dkk, 2018. Keragaan Usaha dan Nilai Tambah Pada Agroindustri

Keripik Tike (Studi Kasus di Desa Jumbleng Kecamatan Losarang Indramayu).

Prodi Agribisnis Fakultas Pertanian. Universitas Padjajaran. Bandung

Surat keputusan Mentri Perindustrian no. 135/M/SK/8/1997.

Tambunan, 2002. Usaha Kecil dan Menengah di Indonesia Beberapa Isu Penting. Jakarta: Penebar Swadaya.

Undang-undang Nomor 9 Tahun 1995. Kriteria Usaha Kecil.

Wardiono, 2007. Eleochardis dulcis Burm. F.) Trinius ex Henschell. http://www.Kehati.or.id/prohati/browser.php/docsid=478. [23 april2008].

Wibisono. 2006. Manajemen Kinerja : Konsep Desain dan Teknik Meningkatkan

Daya Saing Perusahaan, Jakarta : Erlangga. 